\title{
COURTS MARTIAL AND THE CODE OF MILITARY JUSTICE OF THE ROMANIAN ARMY IN WORLD WAR ONE
}

\author{
Colonel Liviu CORCIU ${ }^{590}$
}

\begin{abstract}
The century that passed over the memories of the Great War, as it was called in the era, should allow all of us, no matter what side we had chosen at that time, to think on all aspects of the day-by-day life in the frontline. And to admit as well, that not all the soldiers and officers who had taken part in, were heroes. They were normal people, with hearts and feelings, trapped in an abnormal environment, fighting for their side of "King and Country" against all destructive means of the industrial war. So, it was of great importance to maintain a proper discipline among those troops which were sent day after day in slaughter attacks. And for this reason, was used the military justice and the Code of military justice, named differently by country, but having the same role: to support the war effort. One of the supportive elements was the preemptive effect, the deterrence of any potential act of breaking the discipline. Equally counted the way this contribution came into effect.
\end{abstract}

Keywords: military justice; discipline; court martial; world war; war effort.

When referring to the relationship between military discipline and justice within the British army, British Manual of Military Law ${ }^{591}$ stated: "The object of military law is to maintain discipline among the troops", definition depicting maintenance of discipline amongst troops as the primordial goal, whereas the proper justiciary act, about which there was no reference falling on the secondary place $^{592}$.

Besides every other definition of the term, the urgent need of assurance and maintenance of order and discipline in times of war, which was directly related to army combat capacity and inherently with every country's defense capacity, has caused legislative bodies from most belligerent countries, to adopt judicial norms, specifically coercive instruments, supporting the command act and often (much) too available.

Whether military regulations are involved or specific legislation adopted in critical situations, such as in Romanian legislation $2^{\text {nd }}$ Additional Title to Code of military justice, there is a common feature, namely the harshness of punishments and treatments ready to be applied to those bold enough to cross the line.

Everything in an unhindered attempt of maintaining combat morale and

\footnotetext{
${ }^{590}$ Colonel Liviu Corciu is the Director of the Romanian National Military Archives, Bucharest, Romania.

${ }^{591}$ Manual of Military Law (1914), H.M. Stationery Office, Imperial House, Kingsway, London, 1914, p.6.

${ }^{592}$ Steven R. Welch, Military justice, https://encyclopedia.1914-1918-online.net/article/military_justice, accesed on 25.04.2021.
} 
spirit, of discouraging any potential criminal acts, not only in the operational area, but also behind the front.

According to some authors ${ }^{593}$, between August 1914 and March 1920, approximately 3000 militaries within the British Imperial Army had been sentenced to death by courts martial, especially for acts such as desertion, cowardice in front of the enemy, murder, espionage, rebellion, or hitting a superior rank. Although in $90 \%$ of cases, the sentences had been commuted to imprisonment or hard labor, over 300 of the sentenced had been confirmed, regardless of circumstances, the fact they voluntarily joined the army or that they were a couple of years' underages for soldiering.

In Great Britain, for instance, all the files concerning death sentences had been classified ${ }^{594}$ ever since their enactment, and public access to the information contained within, restricted for 75 years, had been granted only in 1993 . Subsequently, in 2006, all militaries of the armies belonging to the countries which had been part of the British Empire, and who had been sentenced to death and executed during World War One, were rehabilitated post-mortem as a redeeming measure.

In our country, according to annex 2 from „Monografia Justitiei Militare, in timpul războiului nostru" 595 which we shall analyze in the $5^{\text {th }}$ chapter of the current paper, death sentences had been confirmed in 101 cases, and had been applied to 4 officers, 2 sergeants, 9 corporals and 86 soldiers, according to the provisions of the same Code of military justice.

However, the amendments undergone by the Code of military justice had not been singular, but part of an entire legislative package regarding army, which proves prince Carol's constant preoccupation concerning the military institution, which was familiarized with ${ }^{596}$.

Therefore, approximately in the same period, the following laws were passed: The Law of armed power (1872), through which an enhanced importance was given to the permanent army, The Law regarding organization of military headquarters (1882), The Law regarding the General Staff (1883), through which the main missions had been planned and which relied on the similar French law of 1880 , considered to be the most modern of that time.

Certainly, the entire reign of Carol, but especially between 1871-1876 can be identified as the transformation of the Romanian army in a modern army when it comes to military organization, legislation, doctrine and strategy.

The Code of military justice is deemed as a step forward towards Romanian

\footnotetext{
593 Julian Putkowski, Julian Sykes, Shot at Dawn, Executions in World War One by Authority of the British Army Act, Pen \&Sword Books Ltd, Barnsley, 2017, p.11.

${ }^{594}$ Anthony Babington, For the sake of example. Capital courts martial, 1914-1920, Penguin Books, London, 2002, foreword.

${ }^{595}$ The Monography of the Military Justice, during World War One, in Romanian National Military Archives, fond "Colecții Registre Istorice și Jurnale de Operații II", folder 330, ff.1-12.

${ }^{596}$ Liviu Corciu, Codicele (Codul) de justiție militară și modificările sale în perioada premergătoare Războiului de Intregire, in ”Buletinul Universității Naționale de Apărare < Carol I > , no.1/2021, p.22.
} 
modernization of military justice ${ }^{597}$, being successively amended and completed in $1881,1894,1905,1906,1916,1917$, in accordance with social, economic, legislative changes, but also with the attempt of being up-to-date regarding the ever-changing reality of the battlefield, in the unrestful period Europe had been through at the end of $19^{\text {th }}$ century and the beginning of the $20^{\text {th }}$ century.

\section{MILITARY JUSTICE IN ROMANIA, A BRIEF HISTORY}

Even though the beginning of military justice in the Romanian Principalities, institutionally organized, stems from the Organic Regulations' period, courts martial are $20^{\text {th }}$ century military justice specific structures, which existed only during the two World Wars Romania had been through, as well as after World War I had ended, in the areas, where, by law, besiegement had been declared.

The first and foremost references to military justice were comprised in chapter IX of The Organic Regulation of Wallachia, entitled "Aşezământul ostăşesc pentru streaja pămîntenească a Valahiei" ${ }^{\prime 598}$, comprised in part IV "Aşezământul judecătoresc şi disţiplinesc" ${ }^{1599}$, which entailed 141 articles, grouped in two sections.

This valuable code of military laws entered into full force on January $1^{\text {st }}$ 1832 until July 1852, when the Army Criminal Register was adopted, unified for both historical provinces during prince Alexandru Ioan Cuza's reign (1859-1866).

The Army Criminal Register had also an "Supliment pentru starea de impresurare" ${ }^{600}$, inspired by the French, more exactly by The Law of besiegement $t^{601}$ of July $10^{\text {th }}, 1791$, which was handling the instauration of besiegement status as a consequence to some disruptions or interruptions of means of communication, being the very first judicial norm, which approached this issue in our country.

The Code of military justice was adopted in 1873, during prince Carol's reign, which relied on the French code of military justice of 1857.

\section{ABOUT THE CODE OF MILITARY JUSTICE}

The legislative framework for the adoption of the Code of military justice had been created by the Constitution ${ }^{602}$ of 1866 , which paved the way for country modernization and army reorganization process, which was seen, according to military justice, as a fundamental institution of the military body.

\footnotetext{
${ }^{597}$ Petrache Zidaru, Tribunalele militare, un secol şi jumătate de jurisprudenţă (1852-2000), Editura Univers Juridic, Bucureşti, 2006, p.34.

598 The military settlement for the territorial land defense of Wallachia.

599 The Judicial and Disciplinary Settlement.

${ }^{600}$ Addendum for besiegement.

${ }^{601}$ Floarea Șerban, Starea de asediu, starea de urgență - regim juridic, doctrină, legislație, drept comparat, Editura Militară, București, 2005, p. 13.

${ }^{602}$ Monitorul - Jurnal Oficial al României, nr. 142/1/13 ${ }^{\text {th }}$ of June 1866.
} 
The Code of military justice ${ }^{603}$ was neither an original creation of the national law school, nor a sum of experiences generated by the participation of the young Romanian army to different military conflicts, but a copy ${ }^{604}$ of the 1857 French Code of military justice, and entered into force in October, same year.

Since its adoption in 1873, the Code of military justice had undergone a series of legislative amendments successively adopted until 1916, the year Romania entered World War One.

The first amendment occurred in 1881, when 94 out of 270 articles had been essentially amended, and the Code of military justice had been republished, the articles being numerated differently, which determined some opinions according to which we might face a new code of military justice ${ }^{605}$.

One of the most significant amendments of the Code of military justice was the provision that in times of war, the right to recourse may be suspended, measure implemented by the supreme army interest which, in those circumstances would have caused promptness and a tough repression ${ }^{606}$ of any disciplinary crimes.

Besides, the suspension of the right to recourse under the High Royal Decree ${ }^{607}$ no. 2930 of $16^{\text {th }} / 29^{\text {th }}$ September 1916, had been considered one of the most important, and certainly, one of the most controversial measures adopted when it came to military justice It supposed that once the sentenced had been given, it was mandatory to be performed, inherently in cases of death sentence.

In 1884, the Code of military justice had been amended once more, being completed with the Special Code for the Navy, as a consequence for acquiring Dobruja after the Treaty of San Stefano, enshrined by the Treaty of Berlin (1878).

Attaining direct exit to the sea, as well as the development the commercial navy was undergoing, enlarging naval and fluvial borders to over $1000 \mathrm{~km}^{608}$, were the main reasons which naturally led to the development of the Navy.

In 1894, under Law $^{609}$ no.1304/24 ${ }^{\text {th }}$ of March 1894, the First Additional Title was added to the Code of military justice and referred to the establishment of disciplinary councils within regiments.

The disciplinary councils were inspired by the Germans ${ }^{610}$, did not correspond at all to the French model of the Code of military justice of 1873, and it was amended in a practical manner, seeking to relieve permanent councils of war, organized within large echelons, from judging misdemeanors, which were numerous within smaller echelons ${ }^{611}$.

\footnotetext{
${ }^{603}$ Law no. 828/5 April 1873, in Monitorul Oastei, no. 13/12 th of May 1873.

${ }^{604}$ Petrache Zidaru, Tribunalele militare, un secol şi jumătate de jurisprudenţă (1852-2000), p.34.

${ }^{605}$ Dumitru Popescu, Privire istorică asupra Justiţiei Militare din România, Editura Militară, Bucureşti, 1977 , p.70.

${ }^{606}$ Viorel Siserman, Justiţia Militară în România.Tradiţie şi actualitate, Editura Militară, Bucureşti, 2004 , p.99.

${ }^{607}$ Monitorul Oficial, no.135/17 ${ }^{\text {th }}$ of September 1916, p.6266.

${ }^{608}$ Istoria militară a poporului roman, vol. V, Editura Militară, București, 1988, p.97.

${ }^{609}$ Monitorul Oficial, no.290/25 ${ }^{\text {th }}$ of December 1894.

${ }^{610}$ Petrache Zidaru, Tribunalele militare, un secol şi jumătate de jurisprudenţă (1852-2000), p.35.

${ }^{611}$ Dumitru Popescu, Privire istorică asupra Justiţiei Militare din România, p.72.
} 
In 1905, the Code of military justice was amended once more, under Law ${ }^{612}$ no. 2667/ $12^{\text {th }}$ of April 1905, regarding establishment of disciplinary councils within Light Infantry Battalions and Navy, measure deemed as a redeeming act towards the two military entities with a strongly developed corps spirit and specifically distinguished among other troops.

These new amendments had been introduced due to constant increase of the number of these units within the army structure, as well as enhancement of their numbers, therefore, implicitly, there was an increase in indiscipline cases.

The latter significant amendment, according to our analysis criteria of the Code of military justice, occurred under $\mathrm{Law}^{613}$ no. 1025, entitled: "Law regarding amendment of articles: 26, 70, 99, 216, 237, 241 and 256 from the Code of military justice, of article 10 of additional title same code, and the addition in that code of article 224bis".

In the new text, "hard labor during limited time" and "confinement", punitive measures established in the old text for the act committed in the simple version, respectively, affected by aggravating circumstances, have been replaced by "imprisonment".

\section{CRIMES, DELICTS, AND PUNISHMENT IN THE ROMANIAN ARMY}

In the Criminal Code ${ }^{614}$ of 1864, which it has been in force since $1^{\text {st }}$ of May 1865 until $17^{\text {th }}$ of March 1936, the acts were classified in three categories: crimes, delicts and minor offences, and punishment comprised hard labor, detainment, confinement and civic demotion for crimes, and also correctional imprisonment, withdrawal of some civilian, political and family rights, as well as fines starting from 25 lei for delicts, respectively, police imprisonment and fines for minor offences.

The Code of military justice classified acts in two categories: crimes (when speaking about offences, a.m.) and delicts, and the punitive measures were death sentence, hard labor, confinement, detainment and military demotion for offences, respectively, dismissal, public labor, imprisonment and fines for delicts.

The way hard labor was performed, lifelong or for a certain period of time, was directed by art.10 and according to the Criminal Code, in salt or coal mines owned by the state or in penitentiary facilities, in a harsh working conditions and detainment, "chained", according to the law, meaning that it was mandatory for the culprit to be permanently chained and cuffed, including during the night.

Moreover, during the entire performance of the sentence, the condemned were not allowed by the judicial system to have access to their goods or properties

\footnotetext{
${ }^{612}$ Monitorul Oficial, no. 12/1905.

${ }^{613}$ Monitorul Oficial, no. $271 / 9^{\text {th }}$ of March 1906.

${ }^{614}$ The Criminal Code of Romania (1864), published in "Monitorul Oficial", no.240/30 $0^{\text {th }}$ of October 1864; It was later amended in 1874, 1882, 1893, 1894 and 1895. See also: C. Hamangiu, Codul general al României, Editura Librăriei Leon Alcalay, Bucureşti, 1907.
} 
they used to own, and they were also subjected to "civic demotion" during this entire period.

Civic demotion was, generally speaking, an auxiliary punishment, but could be also pronounced as a main punishment, and entailed the dismissal and exclusion of the condemned from every public office, withdrawal of the right to vote, as well as the right to be employed within public educational institutions, or, more importantly, to serve the Romanian army.

In a descending order regarding importance, the next punishment applied by the Code of military justice for offences was confinement, regulated by article no.15 provisions and the following from the Criminal Code, which entailed that the condemned was to perform mandatory labor, which was less severe than hard labor.

He was to be locked in a "labor house" and was to be given certain tasks for which in return he would receive payment, which was to be divided between the state and the condemned. However, unlike the regime imposed for hard labor punishment, confinement allowed that half of payment be given to the condemned during serving of sentence, in order to enhance his stay, whilst the other half was to be granted upon release.

Similarly, to hard labor, upon confinement, the condemned was cuffed and devoid from all civil rights enlisted above.

The next is detainment, regulated by art.20 and the following from the Criminal Code, which did not impose labor as mandatory, the condemned although being detained was allowed to communicate with the outer world, without wearing attire specific to inmates and free to eat whatever he desired, depending on his income.

According to art.182 of the Code of military justice, hard labor, confinement or detainment were applied according to the Criminal Code and were invariably attached to the auxiliary punishment of military demotion.

Military demotion was not regulated by the Criminal Code of then, but by art.183 and art.184 of the Code of military justice, being known, at least in Wallachia ever since the reign of Neagoe Basarab, who, in his teachings towards his son, Teodosie ${ }^{615}$, was talking about military demotion as a punishment established for being drunk.

As civic demotion, military demotion could be established also as auxiliary punishment, attached to the main punishment, save for death sentence, could be also main punishment, but, unlike the former, it took always place in front of the troop gathered "at arms", and obviously seeking, besides the spectacular show, public humiliation, sometimes right before former subordinates.

After the decision of the council of war had been read, the commander selected the condemned, speaking loudly: "You're unworthy to bear the arms; In

\footnotetext{
${ }^{615}$ Gheorghe Cosneanu, Magistratura militară, trecut prezent și viitor, Editura Centrului Tehnic Editorial al Armatei, Bucureşti, 2013, p.20.
} 
the name of the King, we are demoting you" and all his military insignias and decorations were ripped off, and were he an officer, his sword would be broken, then tossed aside.

Military demotion ensued loss of rank, right to bear military insignias, decorations and uniform, as well as the absolute incapacity to serve the army, together with all incapacities provided under art.22 of the Criminal Code, previously presented for civic demotion. Above all these, the loss of right to pension followed as well as the right to benefit from any other means of payment for previous acts.

The first and foremost punishment established by the Code of military justice for delicts was dismissal, regulated under art.185, which ensued loss of rank or office, as well as the right of the condemned to wear uniform. According to this domain's jurisprudence ${ }^{616}$, the dismissed officer could not attain any other reward for his previous services, not even pension, even though the sentence was not specifically mentioning ${ }^{617}$ it.

\section{LEGAL FRAMEWORK OF THE COURTS MARTIAL}

Due to the fact that the Code of military justice was no longer responding to the requirements imposed by mobilization and war stance within the modern war context, ever since February 1916, during the office as premier and ministry of war of liberal Ion I.C. Brătianu, the Minister of War had adopted and submitted to the Parliament a bill, subsequently adopted under Law no. 3245 of December $21^{\text {st }} 1916$, regarding the repeal, amendments and addenda to be done to the Code of military justice in times of mobilization and $\operatorname{war}^{618}$.

The amendment of the Code of military justice through which $2^{\text {nd }}$ Additional Title had been added, was, probably one of the most important legal measures adopted back then, a document which judicially was fundamentally relying on elements regarding military psychology ${ }^{619}$. The entire special theory concerning military justice had been modified, taking into account to its enactment the requirements of urgent suppression of some facts, based on the principle stating that organization of military justice has a crucial role when strengthening and developing military discipline.

The adoption of $2^{\text {nd }}$ Additional Title to Code of military justice caused the abolition of the institution of the disciplinary council, functioning within regiments, Light Infantry Battalions and warships, as well as of councils of war, functioning within army corps and divisions and replacing them with the courts martial, it has also extended territorial competences, as well as competences towards individuals which fell under its jurisdiction.

\footnotetext{
${ }^{616}$ Decision no.279/1893 of the $2^{\text {nd }}$ Section of the Cassation Court, published in „Dreptul”, no.63/1893.

${ }^{617}$ Nicolae Homoriceanu, Codul Justiției Militare adnotat, ediţia a II-a, Tipografia profesională Dim. C. Ionescu, București, 1916, p.144.

${ }^{618}$ Monitorul Oficial, no.224/28 ${ }^{\text {th }}$ of December 1916, pp.7529-7530.

${ }^{619}$ Petrache Zidaru, Tribunalele militare, un secol şi jumătate de jurisprudenţă (1852-2000), p.70.
} 
An entire body of provisions had been added, adequate to the requirements of that time, which was named $2^{\text {nd }}$ Additional Title in order to make a sound distinction with Additional Title I added to the Code of military justice in 1894, dealing with the establishment of disciplinary councils within regiments.

$2^{\text {nd }}$ Additional Title comprised five chapters, first four being dedicated to the new judicial institution established herein, whilst the fifth entailed aggravating circumstances of the acts incriminated by criminal law in times of war, as well as the punitive measures associated.

The adoption of $2^{\text {nd }}$ Additional Title has created the legal framework of sanctioning new offences, such as treason, espionage, self-infliction of wounds, spreading panic, creating or spreading false news, etc.; and led to harsher punishments, seeking a swift and outstanding repression.

Therefore, these acts, which the Criminal Code, the Code of Military Justice, or other provisions of some special laws used to sanction by confinement, or lifelong hard labor or hard labor for a certain amount of time, could, in times of war, be sanctioned by capital punishment, depending on the gravity of the committed act and the circumstances of their commitment.

There were targeted acts such as those that could jeopardize state security, like treason, espionage, instigation towards desertion and joining enemy forces, as well as those that could jeopardize unfolding of military operations, such as disobedience within conscripting or mobilization, desertion, etc. For a clear picture, for this last deed, during the besiegement or wartime, the Code of Military Justice initially set up 2 up to 5 years imprisonment.

Within the same context, the initial provision regarding self-infliction of wounds had been modified, which was not previously provided under the Code of military justice, with all amendments and addenda made until Law no. 3245, but was introduced under $2^{\text {nd }}$ Additional Title.

Since within parliamentary debates regarding Law no.3245, even the deputies had requested aggravation of punishment provided initially, considering it being "a very grave act of shame" "620, under art. 55, in times of war, the capital punishment had been provided both for self- infliction of wounds but also for the infliction of wounds affecting another military, with his own will, as well as for willing aggravation of one's own wounds or another military's.

So much for the court martial denomination, it was not inspired by the French army which kept the original institutional denomination - conseil de guerre- during the entire war, but rather by the British, in order to "be more adequate when it comes to the capital sentences they may pronounce" 621 .

The institution differed from the old council of war by the way it was composed, by where it was functioning, by the individuals' subject to judgment,

\footnotetext{
${ }^{620}$ Library of Defence Staff, III/0124/1, Codul de justiție militară, cu modificările și adăugirile până la 15 septembrie 1917, p.78.

${ }^{621}$ Library of Defence Staff, S.III 124, Instrucțiuni în ce privește curțile marțiale, p.164.
} 
by the acts that were being judged and by the trial procedures.

The competence of the court martial had been originally assigned by the Code of Military Justice to the council of war, more exactly, according to art.51, it could judge any individual who had been recruited to the army, or was under any other kind of employment.

Under Law no.3245 the competences over individuals had been enhanced, having been added every individual serving the army in every way, under any circumstance, denomination and task, as well as the clerks, craftsmen and the entire personnel of every industrial or commercial settlement, commandeered by the army, or which had entered under the control of military authorities.

Courts martial also comprised those everyone who followed the army, as well as everyone who found themselves near army units under an authorization.

Chapter III from $2^{\text {nd }}$ Additional Title, regulated in turn another newlyestablished judicial institution, namely the Superior Court of Military Justice, which replaced the old Permanent Council of Revision, and was deemed as unique for the entire army.

Unlike its successor, the new institution comprised two distinct entities, specifically similar, which in fact were fulfilling the role of the High Court of Cassation for all the judicial authorities of the military criminal courts: was judging the recourse to court martial decisions, were this right wasn't suspended yet.

Also, the two Superior Courts of Military Justice had different competences regarding territoriality: the former was functioning in the vicinity of the General Headquarters being competent for the entire operational area, whilst the second was functioning in Iasi ${ }^{622}$, being competent for the internal area.

Consequently, the appointment of the members of both superior courts were different; appointments for the one functioning in the vicinity of the General Headquarters were made by the King or by the Chief of the General Headquarters, whilst appointments for the one competent for the internal area were made by the head of the War Office.

Regarding the provisions of Chapter IV from $2^{\text {nd }}$ Additional Title, concerning judiciary police, we need to emphasize that it was not regulating a new institution, such as in the other chapters, but it was just changing, in times of war, the competences regarding exertion of attributions of the military judiciary police. This term did not represent a structure within the army, such as the way it is today, for instance, or a distinct specialty, but an abstract institution, perceived concretely as legally empowered to judge ex officio some causes, crimes (offences) or delicts (minor offences).

According to provisions under art.77 of The Code of Military Justice, in times of peace, military judiciary police had the attribution to pursue crimes or delicts, to gather evidence and to facilitate the sending of the accused before the councils of war.

${ }^{622}$ Based on High Royal Decree, no. 48/1917, in Monitorul Oficial, no. 235/10 January 1917, p.7598. 
Modifications regarding attribution exertion by military judiciary police in times of mobilization or war were substantial. The new provisions were attributing the competence to distribute the certain authority to commanders of large units where the offence might have been committed, the fact might have been discovered or the culprit, accomplice or the one keeping the offence secret might have been caught.

The commander of the certain large unit had the right to delegate the exertion authority of military judiciary police attributions to lower echelons, royal commissioners and their substitutes, who in times of peace had exclusive attributions concerning flagrant delicts, to praetors, when being in a territory with no gendarmes or police chiefs, considered common law judiciary police officers, to garrison commanders and their subordinates.

Attributions of military judiciary police officers could be also exerted by a special delegate, assigned for the operational army by the Commander-in-Chief, who was the king himself, while, for the internal area, the special delegate had to be assigned by the head of War Office.

In the closing lines of $2^{\text {nd }}$ Additional Title, Chapter $V$ established aggrieving circumstances for the acts and punishments applicable in times of mobilization or war, enhancing their limits towards those provided in times of peace under the Criminal Code, including those concerning capital punishment.

Although harsh in wording, capital punishments had been rarely applied in the Romanian Principalities, last death sentence by hanging having been performed ${ }^{623}$ in Moldavia in 1847.

In Wallachia, though appearing in 1850 in Barbu Ştirbey's Criminal Code, death sentence had been rarely used in practice maybe also due to lack of an executioner ${ }^{624}$ and had been abolished once with the implementation of the Criminal Code of 1864 and repeated once again with the adoption of the 1866 Constitution, save for cases provided under the Code of military justice.

On the date when Romania joined the First World War, the Code of Military Justice was the only judicial norm within Romanian society which provided death penalty for not less than 24 military offences.

Within this context, capital punishment was perceived as an indispensable instrument, providing a swift solution and a guaranteed effect, unlike imprisonment which could have encouraged soldiers to commit disciplinary offences, only to escape the horrors of the front line. Article 181 of the Code of military justice provided: "Every individual sentenced to death by a council of war, shall be shot" 625 , an important detail considering that from all the methods of performing this sentence, hanging was traditionally reserved to thieves ${ }^{626}$.

\footnotetext{
${ }^{623}$ Iulian Poenaru, Pedeapsa cu moartea, <pro> sau <contra >?, Editura Lumina Lex, București, 1994, p.62.

${ }^{624}$ Iulian Poenaru, op.cit., p.63.

${ }^{625}$ Nicolae Homoriceanu, Codul Justiției Militare adnotat, ediția a II-a, Tipografia profesională Dim. C. Ionescu, București, 1916, p.214.

${ }^{626}$ Dan Horia Mazilu, Lege și fărădelege în lumea românească veche, Editura Polirom, Iași, 2006, p.513.
} 


\section{THE ACTIVITY OF THE MARTIAL COURTS IN ROMANIAN MILITARY IN WORLD WAR ONE}

The activity of martial courts during 1916-1918 campaign was synthesized in: "The Monography of Military Justice, during World War One", previously mentioned, enacted by general Gheorghe Cereșeanu, the Chief of the Military Justice Service of the General Headquarters.

The paperwork had been submitted to the Commission of war monographies from $3^{\text {rd }}$ Section, $3^{\text {rd }}$ Historic Bureau of the General Staff, the predecessor of the actual Romanian National Military Archives, and is a highly valuable source comprising essential information regarding the stance of military discipline, military justice organization, and last but not least, the proportions of the military criminal phenomenon.

Based on the data recorded in the Monography annex, named Statistical and Numerical Panel of Inmates sentenced by Courts martial and Councils of War in the vicinity of the operational army, during the 1916-1918 campaign, until June $1^{\text {st }} 1918$, we may conclude that the most common offence punished by the Code of military justice during this period was desertion, with 2732 sentences having been pronounced ${ }^{627}$.

Out of these, 282 sentences were given by the court martial of $6^{\text {th }}$ Infantry Division, standing for $10,32 \%$ and most of the analyzed structures. Coming up next, in a descending order, $10^{\text {th }}$ Infantry Division court martial with 250 sentences given, counting $9.15 \%$ and the court martial embedded to the General Headquarters, having given 223 sentences, which means $8.16 \%$.

As far as can be noticed the sentences given by the three courts martial of the structures sum up $27.62 \%$ which is more than a quarter of the total sentences that had been given. According to the analysis of the evolution of the two divisions, we learn that both had been involved in battles ever since the beginning of the 1916 campaign, $6^{\text {th }}$ Infantry Division battling near Sfântu Gheorghe and Brasov, and subsequently in Mărăști, whilst $10^{\text {th }}$ Infantry Division had participated in the battles of Mărășești.

As far as the other analyzed offence is being concerned, desertion to enemy and capitulation, we need to specify that this criterion can be found inserted within the Statistical Panel, being in fact a sum of two offences condemned by the Code of Military Justice: desertion to enemy, provided under art.232, respectively, capitulation, provided under art. 202 and art. 203, Code of Military Justice.

1592 sentences had been registered ${ }^{628}$, as being pronounced for desertion to enemy and capitulation, of which the most, 296 were given by the court martial of $15^{\text {th }}$ Infantry Division, counting as $18.59 \%$. Coming up next in descending order is court martial of $12^{\text {th }}$ Infantry Division, with 190 sentences, counting as $11.93 \%$ and court martial of $5^{\text {th }}$ Infantry Division, with 127 sentences, counting as $7.97 \%$.

\footnotetext{
${ }^{627}$ Romanian Miltary National Archives, fond "Colecții Registre Istorice și Jurnale de Operații II", dosar 330, f.7.

${ }^{628}$ Romanian Miltary National Archives.
} 
Although the sentences pronounced by the courts martial of the three structures equal $38.40 \%$, which is more than a third of the total number of sentences for these acts, this percentage can't be found when it comes to death sentences followed up by performance, pronounced for the same act, by the same courts martial.

Within this context, we need to emphasize the fact that art.202, art.203, and art. 232 under The Code of Military Justice which regulated these established a single punishment, the capital one.

Returning to the percentage of sentences given for desertion to enemy, respectively capitulation, offences sanctioned, as we mentioned, by capital punishment, the number of sentences followed by their performance is substantially lower.

Therefore, the court martial embedded to the General Headquarters pronounced two sentences followed by executions, the Martial Court of $10^{\text {th }}$ Infantry Division pronounced one sentence followed by its execution, whereas court martial of $6^{\text {th }}$ Infantry division pronounced none. Calculating the sentences pronounced for desertion from the three structures, the result is 775 sentences, out of which four had been performed, which is $0.31 \%$.

A possible explanation may be that most of these sentences had been pronounced within contumacy, after the guilty person had already deserted to the enemy, and this assertion was in fact the least the military authorities could do.

We found this practice in the documents concerning $6^{\text {th }}$ Infantry Division, which recorded in "The Operational Log" that on March 29 $9^{\text {th }} 1917$, within the first meeting since its establishment, the court martial has judged in contumacy 13 Romanian militaries and 39 Jewish militaries, for desertion to the enemy and abandonment of their posts, ensuing that after cessation of war the cases were to be judged one more time "when those sentenced to death would be able to prove innocent through documents and testimonials" 629 .

The regulation concerning re-judgment had been introduced under Law no. 3245 of $21^{\text {st }}$ of December 1916, regarding suppressions, amendments and addenda to be done to the Code of Military Justice in times of mobilization and $\operatorname{war}^{630}$, which added $2^{\text {nd }}$ Additional Title to the Code of Military Justice. Moreover, $2^{\text {nd }}$ Additional Title tried to solve the issue of Romanian soldiers fallen as POWs, establishing the courts martial had the competence to judge them after cessation of hostilities, when previously to capitulation they could have committed an act incriminated by criminal law.

It's worth mentioning that, under the provisions of the Royal High Decree ${ }^{631}$ no. 783 of March $5^{\text {th }} / 18^{\text {th }} 1918$ for the application of art. 65 of $2^{\text {nd }}$

\footnotetext{
${ }^{629}$ Horia Dumitrescu (coord.), Divizia a VI-a Infanterie, jurnal de operațiuni, vol.I (14 august 1916-14 mai 1918), Editura Pallas, Focşani, 2017, p.297.

${ }^{630}$ Monitorul Oficial, nr.224/28 December 1916, pp.7529-7530.

${ }^{631}$ Monitorul Oastei, partea regulamentară, no.70/9 April 1918, pp.167-170.
} 
Additional Title of the Code of Military Justice, regarding verification of causes of surrendering to enemy of those retrieved from captivity, after peace had been declared, classification commissions were created, one for each army corps.

For generals, these commissions comprised the commander of the army corps and the two subordinated division commanders, whilst, for those who at the moment they had been captured were brigade, troop corps commanders or service chiefs, no matter their rank was, the commission comprised the division commander and two of the brigade commanders, for officers returning from captivity ranked until colonel, whilst for lower ranks verification of causes was made by the chief of the corps they were part of.

To those guilty for acts committed in times of mobilization or war, punishments during war were applied, save for death penalty, which was switched to lifelong hard labor.

Another offence analyzed is abandonment of post for which 239 sentences had been pronounced ${ }^{632}$, out of which the most, 48 , had been pronounced by the court martial of $15^{\text {th }}$ Infantry Division, summing up 20\%. Coming up next, in descending order is the court martial of $10^{\text {th }}$ Infantry Division, 22, summing up 9.2\% and the council of war and court martial of Army I, with 22, respectively 16 sentences, together summing up $15.8 \%$.

Adding up the sentences pronounced for abandonment of post of the three structures, the result is a total of 108 sentences, which is $45.18 \%$, almost half of the total sentences pronounced for this act. Regulated under art.205 of the Code of military justice, the abandonment of post would have been sanctioned by capital punishment were to had been committed within the presence of the enemy, 28 militaries having been sentenced and executed ${ }^{633}, 2$ officers and 26 troop members.

Therefore, as far as the two officers are concerned, their sentences had been pronounced by the council of war of $1{ }^{\text {st }}$ Army, respectively by the court martial of the $2^{\text {nd }}$ Army, and regarding the troop members, generic denomination for lower ranks and non-commissioned officers, sentences had been pronounced, in a descending order, by the court martial of $7^{\text {th }}$ Infantry Division, 12 sentences, council of war of $1^{\text {st }}$ Army, 6 sentences, respectively council of war of $3^{\text {rd }}$ Army Corps, 2 sentences.

Although sentences pronounced by the three structured add up to $45.34 \%$, the percentage report cannot be found when it comes to death sentences followed by execution of the condemned, pronounced for the same act, by the same courts martial or councils of war. Adding up sentences regarding abandonment of post from the three structures, the result is a total of 108 sentences, from which 28 followed up as executions, which stands for $25.92 \%$.

It's worth noticing that this is one of the highest percentages concerning the military offences analyzed so far, fact which may be interpreted as a reassuring

\footnotetext{
${ }^{632}$ Romanian Miltary National Archives, fond "Colecții Registre Istorice și Jurnale de Operații II", dosar 330, f.7.

${ }^{633}$ Romanian Miltary National Archives, fond "Colecții Registre Istorice și Jurnale de Operații II", dosar 330, f.8.
} 
measure of military authority, but also as an acknowledgement of the danger represented by the act itself.

Another remarkable aspect is that the most sentences pronounced for this act had been executed within the first part of the campaign, when military justice was instrumented by councils of war. As mentioned above, no later than January 1917 , once with the adoption of Law no. 3245 of December $21^{\text {st }} 1916$, the legislative framework was modified, opportunity with which councils of war had been abolished and replaced by courts martial.

\section{CONCLUSIONS}

The adoption of coercive measures concerning military justice was not a perfect process. It was even a subject to enough criticism related to the analysis of the legal character of the so created military judiciary system, as well as the legislative steps adopted, most of them subsequently ratified by Parliament.

Other criticism concerns the way itself which military justice was done, following the courts of juror's model, the judges fulfilling the role of jurors and also the role of judges, as well as the fact that military court decisions were not grounded, aspect which could have concealed the arbitrary, removing any possibility of verification.

There has also been criticism regarding lack of judicial instruction of the personnel summoned to perform the act of justice, aspect as real as possible since no sooner than art.74 under The Law about the promotion of army officers ${ }^{634}$, provided that they could be recruited only if they had an university degree in law, and, last but not least, regarding lack of experience and knowledge of law of the officers that had to defend the accused.

It's obvious that military justice during World War I had a prominent rigid character, and we must remind here that the General Headquarters, and not the Ministry of Justice, had to fulfill the measures provided under $2^{\text {nd }}$ Additional Title, through which the courts martial were established ${ }^{635}$.

This fact thus outlines one of the basic elements through which military justice had contributed to support the war effort, namely the dissuasive effect, of preventing any potential act of breaching military discipline ${ }^{636}$.

This principle gained consistency towards the end of 1916, once with the worsening of the situation on the two fronts where the Romanian army was engaged and was poised at providing a corresponding climate for the leading and recovery of military combat capacity.

Although in the synthesis entitled "The Monography of Military Justice during World War One", a lot of statistical data is provided in order to form an

\footnotetext{
634 "Monitorul Oastei”, no. $56 / 25^{\text {th }}$ of December 1911.

${ }^{635}$ Dan Prisăcaru, Petre Otu, Marius Iorgulescu, (coord.), "Contribuția Armatei României și a elitelor la apărarea și recunoașterea internațională a Marii Uniri (1919-1920)", Editura Militară, București, 2020, p.417.

${ }^{636}$ Dan Prisăcaru, Petre Otu, Marius Iorgulescu, (coord.), ”Contribuția Armatei României și a elitelor la apărarea și recunoașterea internațională a Marii Uniri (1919-1920)”, Editura Militară, București, 2020, p.416.
} 
opinion regarding the phenomenon of military justice between 1916-1918, the approach is not chronological, following phases, months or years, according to which the researcher may tell the evolution of the disciplinary phenomenon related to the military and political events on the Romanian front.

For instance, to be able to analyze the evolution of the phenomenon at the end of the 1916 campaign, before or after the military actions of 1917 or, for instance, how the proclamation from Răcăciuni influenced the disciplinary stance of the troops, when king Ferdinand bolstered the morale of the peasant-soldiers promising them the land at the cost of their blood.

However, we can conclude that the coercive measures applied by councils of war, and subsequently by courts martial, aimed to discourage any potential act of indiscipline, by any means at disposal.

\section{BIBLIOGRAPHY}

- AMR (Romanian Military Archives), fond "Colecții Registre Istorice și Jurnale de Operații II".

- AMR, fond Marele Stat Major, Secția a III-a Operații.

- Babington A., For the sake of example. Capital courts martial, 1914- 1920, Penguin Books, London, 2002.

- Codul de justiție militară (Code of Military Justice), updated to $15^{\text {th }}$ of September 1917.

- Codul penal, 1864.

- Corciu L., Codicele (Codul) de justiție militară și modificările sale în perioada premergătoare Războiului de Intregire, https://revista.unap.ro/ index.php/revista/article/view/1013/982.

- Cosneagu G., Magistratura militară, trecut prezent și viitor, Editura Centrului Tehnic Editorial al Armatei, Bucureşti, 2013.

- Dumitrescu H. (coord.), Divizia a VI-a Infanterie, jurnal de operațiuni, (14 august 1916-14 mai 1918), Editura Pallas, Focșani, 2017.

- Homoriiceanu N., Code of Military Justice, adnoted, II ${ }^{\text {nd }}$ edition, Editura Dim. C. Ionescu, București, 1916.

- Istoria militară a poporului român, vol. IV, Editura Militară, București, 1988.

- Manual of Military Law (1914), H.M. Stationery Office, Imperial House, Kingsway, London, 1914.

- Mazilu D.H., Lege și fărădelege în lumea românească veche, Editura Polirom, Iași, 2006.

- Monitorul. Jurnal Oficial al României, 1866.

- Monitorul Oficial, Bucharest, 1894, 1916-1918.

- Monitorul Oastei, Bucharest,1873.

- Poenaru I., Pedeapsa cu moartea, <pro> sau <contra>?, Editura Lumina 
Lex, București, 1994.

- Popescu D.C., Privire istorică asupra Justiţiei Militare din România, Editura Militară, Bucureşti, 1977.

- Prisăcaru D., Otu P., Iorgulescu M., (coord.), Contribuția Armatei României și a elitelor la apărarea și recunoașterea internațională a Marii Uniri (19191920), Editura Militară, București, 2020.

- Putkowski J., Sykes J., Shot at Dawn, Executions in World War One by Authority of the British Army Act, Pen \&Sword Books Ltd, Barnsley, 2017.

- Revista „Dreptul”, nr. 63/1893.

- Siserman V., Justiţia Militară în România. Tradiţie şi actualitate, Editura Militară, Bucureşti, 2004.

- Șerban F., Starea de asediu, starea de urgență - regim juridic, doctrină, legislație, drept comparat, Editura Militară, București, 2005.

- Zidaru P., Tribunalele militare, un secol şi jumătate de jurisprudenţă (18522000), Editura Univers Juridic, București, 2006.

- Welch S.R., Military Justice, https://encyclopedia.1914-1918-online.net/ article/military_justice. 